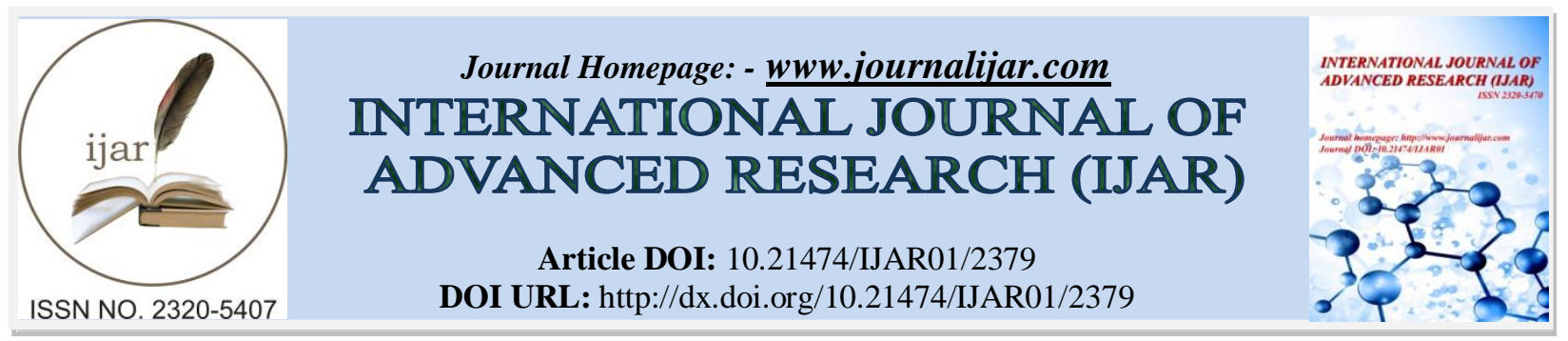

RESEARCH ARTICLE

\title{
IN VITRO ANTICANCER ACTIVITY OF METHANOLIC EXTRACT OF ROOTS OF NAREGAMIA ALATA W\&A.
}

Vinny Kodumpilly Velayudhan*, Prameela Thampy Supratha and Oommen Panavilayil Saj. Department of Botany, University College, Trivandrum, Kerala.

\section{Manuscript Info}

Manuscript History

Received: 19 October 2016

Final Accepted: 20 November 2016

Published: December 2016

Key words:-

N. alata, MTT Assay, A-549, Hep G2,

HeLa Human cancer cell line.

\section{Abstract}

The aim of the study was to evaluate the phytochemical and antiproliferative activity of the methanol extract of the root of $N$. alata by MTT Assay. For evaluation A-549 (Lung), Hep G2 (Liver) and HeLa (Cervical) cell lines were used. Various concentrations of the methanolic root extract were used for this study. Qualitative phytochemical analysis of root extract showed the presence of tannins, flavonoids, terpenoids, alkaloids and glycosides. Root extract showed less anti-proliferative activity against A-549 cell lines showed 59.56 \pm $0.09 \%$ viability at $100 \mu \mathrm{g} / \mathrm{ml}$ of extract and $\mathrm{IC}_{50}$ value was found to be $>100 \mu \mathrm{g} / \mathrm{ml}$. In case of Hep G2 liver human cancer line and HeLa cervical cell line root methanol extract of plant showed $37.70 \pm 0.04 \%$ and $44.66 \pm 0.014 \%$ viability compared with the standard doxorubicin were $26.01 \pm 0.007 \%$ and $34.05 \pm 0.14 \%$ respectively. The $\mathrm{IC}_{50}$ values were found to be $45 \mu \mathrm{g} / \mathrm{ml}$ and $67.5 \mu \mathrm{g} / \mathrm{ml}$ for root methanol extract against Hep- G2 and HeLa cell lines, compared with the standard drug doxorubicin were 16.25 and $25 \mu \mathrm{g} / \mathrm{ml}$ by MTT assay. The extract showed dose dependent anticancer activity. Root extract is more potent against Hep G2 cell lines than A-549 and HeLa cell lines. Hep G2 showed an antiproliferative activity $\left(\mathrm{IC}_{50}\right)$ at $45 \mu \mathrm{g} / \mathrm{ml}$ of crude extract. The results of the present findings were the potential of the selected plant as a resource for the discovery of novel anticancer, agents.

Copy Right, IJAR, 2016,. All rights reserved.

\section{Introduction:-}

Cancer is one of the most prevalent diseases in the world; in the United States only, 1,658,370 new cancer cases and 589,430 cancer deaths have been estimated in 2015. Therefore, improvements in cancer treatment are essential. Natural products have played an important role in the treatment of disease for thousands of years (Mona et al., 2016). Moreover, more than $60 \%$ of all drugs are derived from natural products. Progress has been made in the treatment of some cancers. Unfortunately, the treatments of many common types of cancers such as lung, breast, colon and prostate cancer are still ineffective or incompletely effective. The current effective anticancer agents act principally as cytotoxic agents through various mechanisms of actions including antimetabolites, DNA binding agents, topoisomerase inhibitors, microtubule inhibitors and alkylating agents (Nitin, 2010).

The plant Naregamia alata Wight and Arn. (Family: Meliaceae) commonly known as "Nilanarakam" is a small branching undershrub found in the western and southern parts of India. It is a small handsome woody shrub up to 
$30 \mathrm{~cm}$ in height found mainly on rocky areas. It has been widely used in ayurveda system of medicine to treat diverse ailments. It is used in the treatment of itch, wounds, anemia, enlarged spleen, ulcers, and vitiated conditions of pitta, vata, halitosis, cough, dyspepsia and catarrh. The root is useful as cholagogue, emetic, and expectorant and used in the treatment of rheumatism and acute dysentery. The leaves and stems, combined with bitters and aromatics, are given in decoction for the treatment of biliousness. Whole plant is used to prevent malaria, particularly useful in fever. Root contains an alkaloid 'Naregamin', and other chemical compounds are Hannesane, $\beta$ sitosterol, palmitic and steric acid (Nadkarni, 1976). There are no scientific references regarding the anticancer activity of methanolic extract of $N$. alata root, therefore, the present investigation was undertaken to examine the anticancer activity by MTT assay.

\section{Materials and methods:-}

\section{Plant material:-}

The fresh plant "Nilanarakam" was collected from Elavoor, Ernakulam district; Kerala, India in the month of AprilMay (Flowering season) and the plant was taxonomically identified by Dr. N. Mohanan Scientist, JNTBGRI Palode. The voucher specimen of the plant [Vocher No. 66911] was prepared and deposited at TBGT for further references.

\section{Preparation of plant extract:-}

The root of N. alata was collected from Elavoor, Ernakulam district, Kerala, India. The shade dried (50gm) powder of root was filled in the thimble and extracted with methanol using a Soxhlet extractor. The extract was concentrated by evaporating the solvent using a water bath maintaining at $60-80^{\circ} \mathrm{C}$ at ambient conditions to get a crude methanolic extract devoid of solvents.

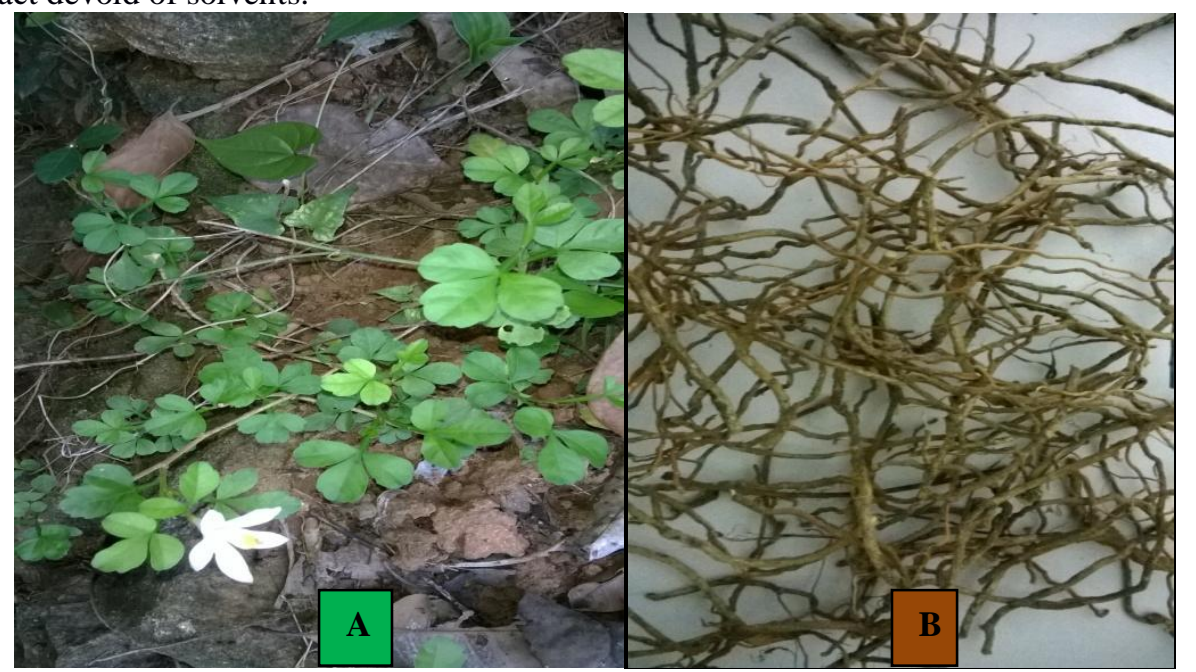

Fig. 1:- Pictures of Naregamia alata Naregamia alata fresh plant (A) and dry (B) Root

\section{Phytochemical screening:-}

The crude extract of plant root was qualitatively tested for the presence of secondary metabolites using standard established methods (Harborne, 1998).

\section{Phytochemical investigation of Naregamia alata root:- \\ Test for Alkaloids (Dragendorff's method):-}

The extract was warmed with $10 \mathrm{ml}$ of $2 \%$ sulphuric acid for 2 minutes and filtered. A known quantity of aliquot was treated with a few drops of Dragendorff's reagent (glacial acetic acid in a solution of bismuth nitrate and potassium iodide) orange brown precipitate denoted the presence of alkaloids.

\section{Test for Glycosides (Keller - Killani test):-}

The extract was dissolved in distilled water and added with $2 \mathrm{ml}$ of glacial acetic acid containing one drop of ferric chloride solution followed by $1 \mathrm{ml}$ of concentrated sulphuric acid along the side of the test tube. Brown ring at the interface denoted the presence of glycosides. 
Test for Terpenoids (Libermann - Burchard method):-

A little of the extract was dissolved in dry chloroform and added three drops of acetic anhydride followed by the addition of two to three drops of concentrated sulphuric acid. Appearance of green colour for steroids while pink colour indicated the presence of terpenoids.

Test for Phenols (Lead Acetate test):-

Alcoholic extract was diluted to $5 \mathrm{ml}$ with distilled water and to this few drops of $1 \%$ aqueous solution of lead acetate was added. A yellow precipitate was formed, which indicates the presence of phenols

Test for Tannins (Ferric Chloride test):-

To 1-2 ml of aqueous extract, few drops of $5 \%$ aqueous $\mathrm{Fecl}_{3}$ solution were added. A bluish-black colour, which disappears in addition of a few $\mathrm{ml}$ of $\mathrm{H}_{2} \mathrm{SO}_{4}$, there is formation of the yellowish brown precipitate.

Test for Flavonoids (Shinoda test):-

The extract was dissolved in methanol and a few pinch of magnesium turnings followed by the addition of concentrated hydrochloric acid drop by drop. Presenceof pink colour confirmed the presence of flavonoids.

\section{Biological screening:-}

\section{Cell lines used:-}

A 549, Hep G2 and HeLa cell lines were obtained [NCCS, Pune]. The cell lines were grown in Dulbecco's modified eagle's media (HIMEDIA) containing 10\% fetal bovine serum.

\section{MTT Assay:-}

The MTT assay of the samples was determined according to the method Arung et al., (2009). This assay measures the reduction of yellow 3-(4, 5 dimethythiazol-2-yl)-2, 5- diphenyltetrazolium bromide (MTT) to form an insoluble formazan precipitated by mitochondrial succinate dehydrogenase only present in viable cells.

The cells were washed with $1 \times \mathrm{PBS}$ and then added $30 \mu \mathrm{l}$ of MTT solution to the culture and incubated at $37^{\circ} \mathrm{c}$ for 3 hours. MTT was removed by washing with $1 \times \mathrm{PBS}$ and $200 \mu \mathrm{l}$ of DMSO was added to the culture. Incubation was done at room temperature for 30 minutes. The solution centrifuged for 2 minutes to precipitate cell debris. Optical density was read at 540nm using DMSO as blank in ELISA reader. DMSO was used as control without the tested compound. The anticancer drug doxorubicin was used as a positive control in the study.

The percentage cell viability and percentage cell death were calculated with the following formulae:

Percentage viability $=(\mathrm{OD}$ of Test $/$ OD of Control $) \times 100$

Cell death $\%=1-(\mathrm{OD}$ of sample/OD of control $) \times 100$

\section{Results and Discussion:-}

Phytochemical analysis conducted on the plant root extract revealed the presence constituents such as alkaloids, glycosides, terpenoids, phenols, tannin and flavanoids.

From MTT assay, methanol extract of root showed positive anti proliferative effect against 3 different human cancer cell lines namely of A-549 (Lung), Hep G2 (Liver) and HeLa (Cervical) at concentrations 6.25, 12.5, 25, 50, $100 \mu \mathrm{g} / \mathrm{ml}$. Against lung (A-549) cell line root extract showed $59.56 \pm 0.09 \%$ viability at $100 \mu \mathrm{g} / \mathrm{ml}$ of extract compared with the standard doxorubicin was $39.43 \pm 0.16 \mu \mathrm{g} / \mathrm{ml}$. The $\mathrm{IC}_{50}$ values were found to be $>100$ and 25 $\mu \mathrm{g} / \mathrm{ml}$ respectively. In case of Hep G2 cancer line and HeLa cervical cell line root methanol extract of plant showed $37.70 \pm 0.04 \%$ and $44.66 \pm 0.014 \%$ at $100 \mu \mathrm{g} / \mathrm{ml}$ (Table:1). The IC 50 values were found to be $45 \mu \mathrm{g} / \mathrm{ml}$ and $67.5 \mu \mathrm{g} / \mathrm{ml}$ for root methanol extract against Hep- G2 and HeLa cell lines compared with the standard drug doxorubicin was 16.25 and $25 \mu \mathrm{g} / \mathrm{ml}$. The above results affirm that the cytotoxicity of the root extract of $N$. alata increased with increase in concentration but the extract showed better activity against Hep G2 cell lines compared with other cell lines.

Plant derived natural products such as flavonoids, terpenoids have received considerable attention due to their diverse pharmacological properties, which include cytotoxic and chemopreventive effects (Siva et al., 2014). The phytochemical biocompounds of $N$. Alata is compared with the available literature of related species such as 
Munronia pinnata (Priya, 2014) who reported the presence of alkaliods, flavonoids, saponins, steroid glycosides and tannins. The presence of flavonoids and tannins in the plant is likely to be responsible for anticancer activities have been reported (Comalada et al., 2004; Mamadalieva et al., 2006), glycosides (Dembitsky, 2006), tannins (Serrano et al., 2006)

Herbal medicines have an important role in the prevention and treatment of cancer. They are commonly available and comparatively economical. They protect the body from cancer by enhancing detoxification functions of the body and some biological response modifiers derived from these herbs are known to inhibit growth of cancer by modulating the activity of specific hormones and enzymes. Latest and previous studies have concluded the beneficial aspects of plant derived drugs as good source of anticancer agents.

The positive response obtained in this assay suggests that the extract may contain antitumor compounds such as terpenoids, phenolic compounds and other secondary metabolites. The test sample showing growth inhibition more than $70 \%$ at $100 \mu \mathrm{g} / \mathrm{ml}$ is considered to be effective (Asima et al., 2012).

Numerous plants have investigated and shown to have cytotoxic activity in cancer cell lines. They include that cytotoxic activity of Limonoids from the seeds of Cipadessa baccifera against A549, MCF-7, ME-180, HT-29, B16, ACHN cancer cell lines using MTT assay, and results indicated that compounds cipaferen H, granatumin E and Febrifugin displayed potent cytotoxic activity against B-16, ACHN cell lines (Siva et al., 2014). Methanolic extract of Cipadessa baccifera showed good cytotoxic activities against EAC and HT-29 cell lines (Pobba, et al., 2015). A flavonoid, quercetin from the leaves of neem tree demonstrated the good anticancer activity with $\mathrm{IC}_{50} \mathrm{of} 50 \mu \mathrm{g} / \mathrm{ml}$ which restricted the proliferation of the HeLa cell lines after 24 hours (Nilima, 2014). From the result it can be concluded that the methanolic root extract of $N$. alata can be alternatively used as the natural product. Further studies on the methanolic root extract are required to isolate and identify the bioactive compounds responsible for its pharmacological activities.

Table 1:- In-vitro anti-proliferative effect of methanolic root extract of Naregamia alata by MTT assay.

\begin{tabular}{|c|c|c|c|c|}
\hline Compound name & $\begin{array}{c}\text { Concentration } \\
(\boldsymbol{\mu g} / \mathbf{m l})\end{array}$ & A549 & $\begin{array}{c}\text { \% Viability } \\
\text { Hep G2 }\end{array}$ & HeLa \\
\hline Root extract & 6.25 & $97.66 \pm 0.44$ & $72.86 \pm 0.24$ & $97.23 \pm 0.31$ \\
& 12.5 & $84.49 \pm 0.33$ & $60.34 \pm 0.21$ & $85.37 \pm 0.27$ \\
& 25 & $72.34 \pm 0.27$ & $59.05 \pm 0.16$ & $70.81 \pm 0.19$ \\
& 50 & $62.77 \pm 0.20$ & $48.76 \pm 0.14$ & $57.97 \pm 0.091$ \\
\hline Doxorubicin & 100 & $59.56 \pm 0.09$ & $37.70 \pm 0.04$ & $44.66 \pm 0.014$ \\
\hline & 12.5 & $66.86 \pm 0.33$ & $87.86 \pm 0.19$ & $90.55 \pm 0.48$ \\
& 25 & $49.8 \pm 0.29$ & $55.28 \pm 0.11$ & $64.58 \pm 0.39$ \\
& 50 & $40.77 \pm 0.17$ & $33.53 \pm 0.04$ & $50.77 \pm 0.27$ \\
& 100 & $39.43 \pm 0.16$ & $26.01 \pm 0.007$ & $44.88 \pm 0.20$ \\
\hline
\end{tabular}

A-549: Human alveolar adenocarcinoma cell line, Hep G2: Human hepato carcinoma cells, HeLa: Human Cervical epithelioid cells, $\mu \mathrm{g} / \mathrm{mL}$ : Micrgram per Millilitre, Values represent in the results are mean \pm SD of three replicates.

Table 2:- IC ${ }_{50}$ Values of Naregamia alata root extracted in methanol in comparison to Doxorubicin

\begin{tabular}{|c|c|c|}
\hline \multicolumn{2}{|c|}{ MTT Assay } \\
\hline Cell lines & Root $(\boldsymbol{\mu g} / \mathbf{m l})$ & Doxorubicin $(\boldsymbol{\mu g} / \mathbf{m l})$ \\
\hline A549 & $>100$ & 25 \\
Hep G2 & 45 & 16.25 \\
HeLa & 67.5 & 25 \\
\hline
\end{tabular}

$\mathrm{IC}_{50}$-half maximal inhibitory concentration

\section{Conclusion:-}

The result of the present study, the root extract showed in vitro cytotoxicity, active against the tested human cancer cell lines. Further studies are necessary to elucidate the chemical structure and the active principle of the root which is responsible for anticancer activity. 


\section{Acknowledgements:-}

We are greatly thankful to the The Director, Biogenix, Mudavanmukal Trivandrum for providing us the laboratory equipments and infrastructure to carry out the work successfully.

\section{References:-}

1. Arung, E.T., Britanto, D.W., Yohana, A.H., Irawan, W.K., Dina, Y. and Ferry, S. (2009): Anti-Cancer Properties of Diethylether Extract of Wood from Sukun (Artocarpusaltilis) in Human Breast Cancer (T47D) Cells. Tropical Journal of Pharmaceutical Research, 8: 317-324.

2. Comalada, M., Ballester, I., Bailon, E., Sierra, S., Xaus, J., Galvez, J., Medina, F.S. and Zarzuelo, A. (2006): Inhibition of pro-inflammatory markers in primary bone marrow-derived mouse macrophages by naturally occurring flavonoids: Analysis of the structure-activity relationship. Biochemical Pharmacology, 72: 10101021.

3. Dembitsky, V.M. (2006): Astonishing diversity of natural surfactants: 5. biologically active glycosides of aromatic metabolites. Lipids. 40: 869-900.

4. Dinesh, M.D., Athira, P.S., Ajma, N., Abhisha, N. and Ashitha, C. (2016): Anti- cancer Activity (Oral) of Betel Leaf Extract by in- vitro. International Journal of Life Science and Scientific Research, 2(4): 412-414.

5. Harborne, J.B. (1998): Methods of extraction and isolation. In: Phytochemical methods. Chapman and Hall London, pp 60-66.

6. Mamadalieva, N.Z., Herrmann, F., EL-readi, M.Z., Tahrani, A., Hamoud, R., Egamberdieva, D.R., Azimova, S.S. and Wink, M. (2006): Flavonoids in Scutellaria immaculata and S. ramosissima (Lamiaceae) and their biological activity. Journal of Pharmacy and Pharmacology, 63: 1346-57

7. Mona, O., Ardalan, P., Dariush, S., Tohid, K., Bahman, Y., Behnaz, A.H., Hosseini. and Behzad, B. (2016): Cytotoxic and Apoptotic Activities of Methanolic Subfractions of Scrophularia oxysepala against Human Breast Cancer Cell Line. Evidence-based Complementary and Alternative Medicine

8. Nadkarni, K.M. (1976): Indian Materia Medica. Bombay Popular Prakashan Private Limited, pp 842.

9. Nilima, S. and Swati, J. (2014): Antioxidant and Anticancer study of the extract of Neem leaves. Bionano frontier, 7:29-31.

10. Nitin, S. (2010): Phytochemical Techniques. Oxford Book Company, pp 256.

11. Priya, G.V. (2014): Antioxidant activity of Soymida febrifuga roxb. International Journal of Pharmaceutical Science and Research, 5(5): 1847-1851.

12. Siva, B., Poornima, B., Venkanna, A., Prasad, K.R., Sridhar, B. and Nayak, V.L. (2014):

13. Methyl angolensate and mexicanolide-type limonoids from the seeds of Cipadessa baccifera. Phytochemistry, 98:174-82.

14. Serrano, J., Puupponen-pimia, R., Dauer, A., Aura, A.M. and Saura-calixto, F. (2006):

15. Tannins: Current knowledge of food sources, intake, bioavailability and biological effects.

16. Molecular Nutrition and Food Research, 53(2): 310-129.

17. Mossi, A.J., Mazutti, M., Paroul, N., Corazza, M.L., Dariva, C., Cansian, R.L. and Oliveira, J. V. (2006): Chemical variation of tannins and triterpenes in Brazilian populations of Maytenus ilicifolia Mart. Ex. Reiss. Braz. Journal of Biology, 69: 339-345.

18. Siva, B., Poornima, B., Venkanna, A., Prasad, K.R., Sridhar, B. and Nayak, V.L. (2014): Methyl angolensate and mexicanolide-type limonoids from the seeds of Cipadessa baccifera. Phytochemistry, 98:174-82.

19. Pobba, R., Rama, K.M., Jayaveera, K.N. and Chandrasekhar, K.B. (2015): Evaluation of antioxidant and anticancer activities of Cipadessa baccifera. Asian Journal of pharmaceutical and Clinical Research, 8:312315 . 